\title{
The omega-3 and Nano-curcumin effects on vascular cell adhesion molecule (VCAM) in episodic migraine patients: a randomized clinical trial
}

\author{
Mina Abdolahi ${ }^{1}$, Elmira Karimi ${ }^{2}$, Payam Sarraf ${ }^{3,4}$, Abbas Tafakhori ${ }^{3,4}$, Goli Siri ${ }^{5}$, Farahnaz Salehinia ${ }^{5}$, \\ Mohsen Sedighiyan ${ }^{6}$, Behzad Asanjarani ${ }^{5}$, Mostafa Badeli ${ }^{7}$, Hamed Abdollahi ${ }^{8}$, Niyoosha Yoosefi ${ }^{9}$, \\ Abolghasem yousefi ${ }^{8}$, Amir Shayegan rad ${ }^{6}$ and Mahmoud Djalali ${ }^{6 *}$
}

\begin{abstract}
Objective: The purpose of this clinical trial was to examine the effect of omega-3 fatty acids (W-3 FAs), nanocurcumin and their combination on serum levels and gene expression of VCAM in patients with episodic migraine.

Results: In this study, 80 patients were randomly divided in to 4 groups to receive for 2 months. Both serum levels and gene expression of VCAM showed remarkable decreases after single W-3 and after combined W-3 and nanocurcumin interventions. However, a borderline significant change and no remarkable change were observed after single nanocurcumin supplementation and in control group, respectively. While a significant difference between study groups in VCAM concentrations existed, there was no meaningful difference in VCAM gene expression among groups. It appears that the W-3 and combined W-3 and nanocurcumin can relieve VCAM serum level and its gene expression in patients with episodic migraine. Moreover, the combination of W-3 with nanocurcumin might cause more significant declines in VCAM level in the serum of migraine patients than when W-3 is administered alone.

Trial Registration: This study was registered in Iranian Registry of Clinical Trials (IRCT) with ID number: NCT02532023.
\end{abstract}

Keywords: Migraine, Vascular cell adhesion molecule, Gene expression, Serum concentration, Omega-3,

Nanocurcumin

\section{Introduction}

Migraine is a neurovascular disturbance characterized by throbbing, unilateral headaches accompanied by photophobia, intolerance of light and autonomic features [1]. Neurogenic inflammation enhances sensitivity of the as nociceptors [2] which up-regulate the secretion of proinflammatory factors $[3,4]$. These cytokines trigger the

\footnotetext{
*Correspondence: mjalali87@yahoo.com

${ }^{6}$ Department of Cellular and Molecular Nutrition, School of Nutritional Sciences and Dietetics, Tehran University of Medical Sciences, Poursina Street, PO Box: 14155-6446, Tehran, Iran

Full list of author information is available at the end of the article
}

permeability of vascular system, suggesting a mechanistic role of them in elevating the expression of endotheliumderived products such as VCAM, ICAM and selections resulted in headaches severity $[5,6]$.

Based on evidences the proinflammatory cytokines such as TNF- $\alpha$ are vasodilators and induce VCAM expression. These are associated with microglia activation which causes brain inflammation and neuropathic pain $[5,6]$. Several medications used to treat migraines include NSAIDs, tricyclic antidepressants such as amitriptyline, COX-2 inhibitors, and sodium valproate [7]. The pain-alleviating power of most of migraine drugs is 
due to their anti-inflammatory effect and preventing from expression of endothelium-derived factors [8-14]. Valproate sodium inhibits mRNA expression of endothelial inflammation mediators including TNF- $\alpha$, IL- $1 \beta$ and IL- 6 as well as $\mathrm{T}$ and $\mathrm{B}$ cells accumulation in macrophages $[8,9]$. It also inhibits NF- $\mathrm{kB} / \mathrm{iNOS}$ signaling resulted in reducing endothelial inflammation [10]. NSAIDs and Cox-2 inhibitors suppress activated endothelial and pain by inhibiting cyclooxygenase enzyme and gene expression of inflammatory endothelial factors (VEGF) [11, 12]. Amitriptyline that widely used in the treatment of migraine, can inhibit the ICAM-1, VCAM-1, iNOS, and COX-2 expression lead to inhibiting endothelial-derived inflammation [14].

Existing evidences have shown that W-3 and curcumin have the same anti-inflammatory effects as the drugs in migraine treatment without any serious side effect $[15$, 16].

Curcumin have no significant side effects, even in doses higher than $10 \mathrm{~g}$ [17]. The nano-curcumin increases the absorption of curcumin up to 40-fold in rats and 27-fold in humans and [18] is safe up to a dose of $210 \mathrm{mg}$ [19]. A meta-analysis showed that curcumin up to $6 \mathrm{~g}$ is completely safe [20]. In the case of W-3, a meta-analysis demonstrated that consumption omega-3 (DHA + EPA) up to $4 \mathrm{gr}$ is safe and has no significant side effect [21]. Additionally, in previous clinical trials, a combination of 2.5 gr of omega-3 and $80 \mathrm{mg}$ of nanocurcumin was well tolerated and had no side effects $[22,23]$.

There are promising findings regarding the efficacy of W-3 and curcumin on VCAM reduction [24-27]. Moreover, some scientific documents have reported the elevated anti-inflammatory activity of lower dosages of W-3 and curcumin, when prescribed in combination [22, 23 ,
28-31]. This study aimed to examine the efficacy of supplementation with W-3, nanocurcumin and their combination on serum concentrations and mRNA expression of VCAM in patients with episodic migraine.

\section{Main text \\ Method and materials \\ Design and population}

Among 285 subjects who attended to Sina hospital neurology clinic in Tehran, 80 men and women were recruited to this double-blind (neither the participants nor the experimenters) randomized controlled trial on July 2015. Participants were adults and had a current diagnosis of episodic migraine in accordance with the IHS criteria ( $\geq 15$ headache days per month for more than 3 months or $\geq 1$ attack per week) [32]. All recruiting criteria are shown in Table 1.

\section{Omega-3 and nanocurcumin supplementation}

The stratified randomization method based on sex and BMI was used to assign participants in 4 groups to receive 2 months supplementation of Group 1) 2 capsules containing $600 \mathrm{mg} \mathrm{EPA}+300 \mathrm{mg} \mathrm{DHA}+100 \mathrm{mg}$ other $\mathrm{W}-3+1$ nanocurcumin placebo, Group 2) 1 capsule containing $80 \mathrm{mg}$ nanocurcumin $+2 \mathrm{~W}-3$ placebo, 3) 2 capsules containing $600 \mathrm{mg}$ EPA $+300 \mathrm{mg}$ DHA $+100 \mathrm{mg}$ other W-3+1 capsule containing $80 \mathrm{mg}$ nanocurcumin (group 3) and 4) $2 \mathrm{~W}-3$ placebo +1 nanocurcumin placebo (control group).

Omega 3 supplement (Omega MAX) and its placebo that were completely similar in shape and color were provided by Zahravi Pharmaceutical Company. Each $1250 \mathrm{mg}$ capsule of W-3 contains $600 \mathrm{mg}$ of EPA, $300 \mathrm{mg}$ of DHA, $100 \mathrm{mg}$ of other W-3 FAs, gelatin, glycerin and pure water.

Table 1 Inclusion and exclusion criteria

\begin{tabular}{|c|c|c|}
\hline $\begin{array}{l}\text { People were considered as eligible if they } \\
\text { meet all of the following criteria }\end{array}$ & $\begin{array}{l}\text { People did not enter the trial if they meet } \\
\text { one or more of the following criteria }\end{array}$ & $\begin{array}{l}\text { Participants were excluded during the trial } \\
\text { if they meet one or more of the following } \\
\text { criteria }\end{array}$ \\
\hline BMl greater than or equal to $18.5 \mathrm{~kg} / \mathrm{m} 2$ & $\begin{array}{l}\text { A history or current diagnosis of kidney, liver } \\
\text { or thyroid disorders, heart diseases, diabetes, } \\
\text { different malignancies and other inflammatory } \\
\text { comorbidities }\end{array}$ & $\begin{array}{l}\text { Allergic reaction to W-3 or nanocurcumin supple- } \\
\text { ments }\end{array}$ \\
\hline Males and females $20-50$ years of age & Low BMI (less than 18.5 kg/m2) & Lack of patient's cooperation \\
\hline Episodic migraine & $\begin{array}{l}\text { Dietary supplementation during the preceding } \\
\text { three months }\end{array}$ & Pregnancy during the study period \\
\hline $\begin{array}{l}\text { Stable diet, physical activity or supplements } \\
\text { during the trial }\end{array}$ & Pregnancy, lactation & Self-reported changes in diet and lifestyle \\
\hline \multirow[t]{2}{*}{ willingness to participate } & Menopause & Changes in dosage or type of routine medications \\
\hline & $\begin{array}{l}\text { Alcohol or drug abuse and cigarette smoking } \\
\text { during } \\
\text { the preceding six months }\end{array}$ & $\begin{array}{l}\text { Over } 2 \text { weeks anti-inflammatory drugs consump- } \\
\text { tion }\end{array}$ \\
\hline
\end{tabular}


Nanocurcumin supplement (Sinacurcumin 80) and its placebo, which were completely similar in shape and color, were prepared by Sinacurcumin Pharmaceutical Company. Each $80 \mathrm{mg}$ nanocurcumin capsule contains approximately $100 \%$ curcumin along with much lower amounts of other compounds such as curcuminoid, emulsifier (polysorbate), gelatin and glycerin. Both omega-3 and nano-curcumin placebo were made from oral paraffin.

Random allocation and enrolling participants to the study were done by trained people who were outside the investigation. Administration of $25-50 \mathrm{mg}$ three cyclic antidepressants (amitriptyline or nortriptyline) and 20-40 mg of $\beta$-blockers (eg propranolol) along with study supplements was given to all groups. Patients were asked to abstain from altering their dietary and physical activity during the intervention. We instructed patients to consume NSAIDS in times of severe headache attacks. To control the bias of NSAID consumption, patients were trained that taking of these drugs should not exceed two weeks during the two months of study and if they take more than this amount, they will be excluded from the study. Patients were asked to record the type and number of medications taken. In our study, none of the patients had used analgesia for more than a week during the study.

\section{Questionnaires}

A predesigned questionnaire was used to consider general characteristics of migraine patients including gender, age, financial perception, migraine duration, educational status, history of other diseases and use of medications and dietary supplements. Severity, numbers and duration of headaches were examined by a trained clinician. Scales for headache severity was within 1-10 in which score 1 and 10 were indicative of minimum and maximum pain of headaches.

\section{Anthropometric indices}

Measured anthropometric indices included: i) weight (through 803, Seca Clara, Germany with $0.1 \mathrm{~kg}$ accuracy with light clothing and no shoes); ii) height (by a stadiometer (Seca) with $0.1 \mathrm{~cm}$ accuracy); and iii) WC (with a common tape after normal exhalation).

\section{Statistical analysis}

Sample size was computed based on the VCAM-1 variable considering the difference of $1.817 \mathrm{ng} / \mathrm{dl}$ between the intervention and control groups via the following formula $($ If $\alpha=0.05,1-\beta=1.28$ (Power $=90 \%)$ [33].

$$
\mathrm{n}=\left(\frac{\mathrm{Z} 1-\alpha / 2+\mathrm{Z} 1-\beta}{\mathrm{d}}\right)^{2}
$$

$\mathrm{N}=17$ was obtained for each study group. By considering $20 \%$ missing during intervention, 20 subjects were selected for each study groups. Data normality was checked through Kolmogorov-Smirnov distribution. For comparison of normal quantitative data means among groups and in each group, ANOVA paired t-tests were conducted, respectively. We used kruskal-wallis and Wilcoxon to compare abnormal quantitative variables between groups and in each single group, respectively. We conducted ANCOVA test to compare study outcomes between groups with adjustment of confounding factors (BMI, energy intake and age). The data were finally analyzed by SPSS version 22 , in which P-value $\leq 0.05$ was considered as significant.

\section{Measurement of serum concentration and gene expression of VCAM}

Laboratory measurements were done at Tehran University of Medical Sciences. At baseline and after 2-month intervention, two blood samples from subjects were collected including $10 \mathrm{ml}$ in tubes containing heparin for PBMCs separation and $5 \mathrm{ml}$ for serum separation. Total RNA from cells were obtained using RNeasy Plus Mini Kit (Qiagen, Valencia, CA, USA). The purified RNA was reversed to synthesis of DNA using QuantiTect Reverse Transcription Kit (Qiagen, Germany). In the PCR step, appropriate primer for VCAM was designed using Primer Express 3 software (Applied Biosystems). Whole genome sequences of VCAM primer were forward: 5'-TAGCGTGTACCCCCTTGACC-3' and reverse: 3'-AACTTAGCCTGACAAACAAGAGC-5'. PCR Analysis were performed by StepOne system (Applied Biosystems, Foster City, CA, USA) using $7 \mu \mathrm{L}$ of Enzymes (Taq polymerase, SYBR Green, etc.), $2 \mu \mathrm{L}$ of cDNA, $0.5 \mu \mathrm{L}$ of each forward and reverse primers in an ultimate volume of $20 \mu \mathrm{L}$ [34]. VCAM expression calculation was conducted by $\mathrm{Ct}(2-\Delta \Delta \mathrm{Ct})$ equation. Blood serums were stored in $-80{ }^{\circ} \mathrm{C}$ until serum VCAM analysis via ELISA method (Bioassay Technology Laboratory, Chain).

\section{Results \\ Basic patient information}

From the 80 individuals (20 participants in each group), 6 subjects (1 woman in group 1, 1 woman in group 2 and 1 woman and 2 mans in group 3 and 1 woman in group 4 ) did not continue with the trial because of changing their treatment trends or drugs (Additional file 1: Figure S1). No serious harms or unintended effects were reported from study supplements and compliance rate of the patients was $100 \%$. A summary of baseline characteristics of participants is demonstrated in Table 2. No significant between-group differences in general, biochemical and clinical characteristics was detected $(P>0.05)$. 
Table 2 Baseline characteristic of participants

\begin{tabular}{|c|c|c|c|c|c|}
\hline \multirow[t]{2}{*}{ Characteristic } & \multicolumn{4}{|l|}{ Groups } & \multirow[t]{2}{*}{ P-value } \\
\hline & $\begin{array}{l}\text { Group } 1 \\
(\mathrm{~N}=19)\end{array}$ & $\begin{array}{l}\text { Group } 2 \\
(\mathrm{~N}=19)\end{array}$ & $\begin{array}{l}\text { Group } 3 \\
(\mathrm{~N}=17)\end{array}$ & $\begin{array}{l}\text { Group } 4 \\
(\mathrm{~N}=19)\end{array}$ & \\
\hline Gender (female/male) & $(16 / 4)$ & $(16 / 4)$ & $(16 / 4)$ & $(16 / 4)$ & \\
\hline Age & $36.20 \pm 1.89$ & $37.10 \pm 1.78$ & $36.90 \pm 1.84$ & $36.45 \pm 1.87$ & 0.97 \\
\hline Weight (kg) & $69.45 \pm 2.75$ & $71.65 \pm 3.80$ & $69.25 \pm 2.51$ & $70.95 \pm 2.31$ & 0.92 \\
\hline Height (cm) & $162.70 \pm 1.92$ & $161.25 \pm 1.76$ & $162.80 \pm 1.97$ & $162.20 \pm 1.52$ & 0.92 \\
\hline $\mathrm{WC}(\mathrm{cm})$ & $79.80 \pm 1.57$ & $83.30 \pm 2.20$ & $80.60 \pm 1.67$ & $83.20 \pm 1.65$ & 0.39 \\
\hline BMI $\left(\mathrm{kg} / \mathrm{m}^{2}\right)$ & $26.23 \pm 0.94$ & $27.29 \pm 1.04$ & $26.17 \pm 0.84$ & $27.13 \pm 0.87$ & 0.75 \\
\hline $\mathrm{El}(\mathrm{kcal})$ & $1612.12 \pm 173.04$ & $1703.79 \pm 215.20$ & $1592.36 \pm 105.53$ & $1410.69 \pm 68.15$ & 0.11 \\
\hline VCAM gene expression & $15.67 \pm 0.53$ & $15.74 \pm 0.74$ & $15.55 \pm 0.89$ & $14.58 \pm 0.69$ & 0.92 \\
\hline Serum VCAM concentration (ng/dl) & $4.90 \pm 1.15$ & $4.18 \pm 0.72$ & $4.75 \pm 1.06$ & $4.94 \pm 1.22$ & 0.99 \\
\hline Headache attacks (number per week) & $2.81 \pm 0.31$ & $2.77 \pm 0.26$ & $2.72 \pm 0.40$ & $2.76 \pm 0.24$ & 0.99 \\
\hline Headache severity (scoring from 0-10) & $7.52 \pm 0.44$ & $7.36 \pm 0.46$ & $7.47 \pm 0.48$ & $7.39 \pm 0.46$ & 0.99 \\
\hline Headache duration (hours) & $7.44 \pm 1.80$ & $7.68 \pm 1.77$ & $7.28 \pm 1.77$ & $7.34 \pm 1.43$ & 0.99 \\
\hline
\end{tabular}

ANOVA test; BMI Body mass index, El Energy intake. Data are presented as mean $\pm \mathrm{SE}$ (standard error)

Table 3 Comparison of study outcomes between study groups before and after supplementation in each group

\begin{tabular}{|c|c|c|c|c|c|c|}
\hline \multirow[t]{2}{*}{ Parameters } & \multirow[t]{2}{*}{ Time } & \multicolumn{4}{|l|}{ Groups } & \multirow[t]{2}{*}{ P-value } \\
\hline & & $\begin{array}{l}\text { Group } 1 \\
(\mathrm{~N}=19)\end{array}$ & $\begin{array}{l}\text { Group } 2 \\
(\mathrm{~N}=19)\end{array}$ & $\begin{array}{l}\text { Group } 3 \\
(\mathrm{~N}=17)\end{array}$ & $\begin{array}{l}\text { Group } 4 \\
(\mathrm{~N}=19)\end{array}$ & \\
\hline \multirow[t]{4}{*}{ VCAM gene expression } & Before & $15.67 \pm 0.53$ & $15.74 \pm 0.74$ & $15.55 \pm 0.89$ & $14.58 \pm 0.69$ & 0.92 \\
\hline & After & $13.99 \pm 0.95$ & $14.09 \pm 0.87$ & $13.34 \pm 0.90$ & $14.02 \pm 0.61$ & 0.63 \\
\hline & Change & $-1.68 \pm 0.82$ & $-1.64 \pm 0.85$ & $-2.21 \pm 0.56$ & $0.55 \pm 0.61$ & 0.46 \\
\hline & P-value & 0.05 & 0.06 & 0.001 & 0.37 & \\
\hline \multirow[t]{4}{*}{ Serum VCAM concentration (ng/dl) } & Before & $4.90 \pm 1.15$ & $4.18 \pm 0.72$ & $4.75 \pm 1.06$ & $4.94 \pm 1.22$ & 0.99 \\
\hline & After & $4.40 \pm 1.11$ & $3.88 \pm 0.72$ & $3.50 \pm 0.74$ & $4.84 \pm 1.21$ & 0.94 \\
\hline & Change & $-0.50 \pm 0.34$ & $-0.30 \pm 0.21$ & $-1.24 \pm 0.42$ & $-0.09 \pm 0.18$ & 0.05 \\
\hline & P & 0.02 & 0.06 & 0.004 & 0.19 & \\
\hline \multirow[t]{4}{*}{ Headache attacks (number per week) } & Before & $2.81 \pm 0.31$ & $2.77 \pm 0.26$ & $2.72 \pm 0.40$ & $2.76 \pm 0.24$ & 0.99 \\
\hline & After & $1.82 \pm 0.27$ & $1.67 \pm 0.42$ & $0.62 \pm 0.08$ & $2.22 \pm 0.38$ & 0.009 \\
\hline & Change & $-0.98 \pm 0.33$ & $-1.10 \pm 0.33$ & $-2.09 \pm 0.34$ & $-53 \pm 0.32$ & 0.01 \\
\hline & P-value & 0.009 & 0.004 & $<0.001$ & 0.11 & \\
\hline \multirow[t]{4}{*}{ Headache severity (scoring from $0-10$ ) } & Before & $7.52 \pm 0.44$ & $7.36 \pm 0.46$ & $7.47 \pm 0.48$ & $7.39 \pm 0.46$ & 0.99 \\
\hline & After & $5.86 \pm 0.48$ & $5.42 \pm 0.52$ & $5.02 \pm 0.56$ & $6.78 \pm 0.43$ & 0.02 \\
\hline & Change & $-1.65 \pm 0.44$ & $-1.94 \pm 0.49$ & $-2.44 \pm 0.41$ & $-0.60 \pm 0.48$ & 0.04 \\
\hline & P-value & 0.001 & 0.001 & $<0.001$ & 0.22 & \\
\hline \multirow[t]{4}{*}{ Headache duration (hours) } & Before & $7.44 \pm 1.80$ & $7.68 \pm 1.77$ & $7.28 \pm 1.77$ & $7.34 \pm 1.43$ & 0.99 \\
\hline & After & $6.02 \pm 1.36$ & $5.26 \pm 1.66$ & $4.15 \pm 1.47$ & $6.68 \pm 1.13$ & 0.64 \\
\hline & Change & $-1.42 \pm 0.96$ & $-2.42 \pm 0.67$ & $-3.12 \pm 0.96$ & $0.65 \pm 1.03$ & 0.26 \\
\hline & P-value & 0.15 & 0.002 & 0.005 & 0.53 & \\
\hline
\end{tabular}

VCAM Vascular cell adhesion molecule

${ }^{* * *}$ AVCOVA test (adjusted for BMI, age and energy intake)

**Kruskal-Wallis test

*Wilcoxon test (Two related sample) 


\section{Outcome assessment}

Table 3 summarizes the results of the study. Two-month supplementation in group 1 and 3 caused statistically significant reductions of both expression and serum levels of VCAM in the participants. Additionally, there were near to significant changes in VCAM serum levels and gene expression in group 2. No meaningful change in study outcomes was observed in control group. Moreover, significant difference was presented in VCAM serum concentrations among all groups. Although, VCAM expression difference between 4 groups was not significant.

\section{Discussion}

Our study for the first time, evaluates whether W-3, nanocurcumin and their combination could reduce serum levels and mRNA expression of VCAM in episodic migraine. This research showed that single W-3 and accompanied W-3 and nanocurcumin supplementation for 2 months led to significant decreases in gene expression and blood levels of VCAM in participants. As we expected, the change of both outcomes in group 3 was greater than group 1. The changes of VCAM serum concentrations was significant within 4 groups. However, VCAM expression was not statistically significant among 4 groups of trial, perhaps due to small sample size. Previously, we found treatment with combined W-3 and nanocurcumin caused meaningful reductions in severity and frequency of migraine headaches [22]. We suspect greater reductions in serum concentrations when accompanied W-3 and nanocurcumin are administered in migraine patients might be one of the underlying mechanisms for the significant alleviation in headaches severity and frequency in comparison to when they are administered alone might. The findings of the current intervention contradict with Poreba et al.s study where W-3 had no effect on serum VCAM in obese population [35]. A meta-analysis reported no meaningful effect of W-3 on serum VCAM [36]. These results could be due to differences in study duration, population and W-3 dosage. To date, there is no study on the investigation of accompanied W-3 and nanocurcumin supplementation on endothelial factors in human. Our findings were inconsistent with Liu et al.s study in mice that showed the significant decreasing effect of curcumin supplementation on VCAM expression (37). This controversy could be due to differences between human and animal studies. Experimental studies have demonstrated W-3 suppress VCAM-1 expression by inhibition of PPAR- $\gamma$ [38], IRF-1 and miR-126 expression (39), sirtuin-1 production [40] and nuclear factor of kappa light polypeptide gene enhancer in B-cells inhibitor, alpha $(\mathrm{I} \kappa \mathrm{B} \alpha)$ and NFKB phosphorylation [41] which are involved in vascular adhesion molecules formation. These FAs also inhibit macrophage activity and decrease the VCAM-1 levels resulted in attenuating severity of migraine headaches [42].

The next mechanism of W-3 against VCAM elevation is up-regulating influence of $\mathrm{W}-3$ on the TREK1 potassium channels as maintainers of the blood-brain barrier integrity which has been to block VCAM transition from the vessel [43]. Curcumin may reduce VCAM levels by down-regulating the phosphorylation of PI3-kinase/Akt, p38 MAPK and JNK [44] and NFKB expression (45), the migration and proliferation T-cells $[37,46]$, induction of anti-oxidative enzymes [47] and reduction of the expression and transcriptional activity of histone acetyltransferases including AP-1 and p300 which can effectively prevent VCAM production [48, 49].

Based on the results of current and previous studies, we suspect more reduction in VCAM serum level might be one of the mechanisms underlying the greater alleviations in severity and frequency of headaches observed in episodic migraine patients after combined W-3 and nanocurcumin interventions than single W-3 or nanocurcumin supplementations. Further researches are needed to confirm the evidence of the current investigation.

\section{Limitations}

There were several limitations including small sample size and short duration of study. Additionally, the mechanistic explanations in the experimental studies mentioned in this study should be attributed to human with caution due to the different conditions exist in cell cultures and animal models [35].

\section{Abbreviations}

MIDs: Mitochondrial disorders; VNs: Vasoactive neuropeptides; VCAM: Vascular cell adhesion molecule; ICAM: Intercellular adhesion molecule; NSAIDs: Nonsteroidal anti-inflammatory drugs; W-3 FAs: Omega-3 fatty acids; NFkB: Nuclear factor-kB; HIS: Internatioanl Headache Society; PCR: Polymerase chain reaction; BMI: Body mass index; EPA: Eicosapentaenoic acid; DHA: Docosahexaenoic acid; PBMCs: Peripheral blood mononuclear cells; WC: Waist circumference; SPSS: Statistical Package for Social Sciences; ANOVA: Analysis of variance; ANCOVA: Analysis of covariance; IRF-1: Interferon regulatory factor; PPAR-y: Peroxisome proliferator-activated receptor gamma; miR-126: MicroRNA 126; IKBa: Nuclear factor of kappa light polypeptide gene enhancer in B-cells inhibitor, alpha; PI3-kinase: Phosphoinositide 3-kinases; Akt or PKB: Protein kinase B; p38 MAPK: P38 MAP Kinase; JNK: C-Jun N-terminal kinases; AP-1: Activator protein 1.

\section{Supplementary Information}

The online version contains supplementary material available at https://doi. org/10.1186/s13104-021-05700-x.

Additional file 1: Figure S1. Flow chart for the clinical trial. This Flow chart shows the number of participants in the four study groups, the number of missing in every group as well as participants entered to the analysis. 


\author{
Acknowledgements \\ We kindly acknowledge those who participated in this research.
}

\section{Authors' contributions}

MA, MS and AT contribute to the conception or design of the work. EK, GS and PS contribute to interpretation of data for the work. AS, BA and MB contribute to drafting manuscript. NY, FS and HA contribute to analysis the data. Ay revised the manuscript. The study was conducted under supervision of $\mathrm{MJ}$. The final version of manuscript should to be published has been final approved by all authors. All authors agreed to all aspects of the work and are insured that all questions related to the accuracy or integrity of any part of the work are appropriately investigated and resolved.

\section{Funding}

None.

\section{Availability of data and materials}

The datasets supporting this article results are included within the manuscript. More information could be available by contact with this email address: Elmira.karimii1994@gmail.com.

\section{Declarations}

\section{Ethics approval and consent to participate}

Present investigation was approved by the Ethics Committee of Tehran University of Medical Sciences, Tehran, Iran (with ID number: IR.TUMS.REC.1394.462) and registered in the ClinicalTrials.gov (ID: NCT02532023). The Participants completed a written consent prior of including into the study and being informed about study protocol.

\section{Consent for publication}

Not Applicable.

\section{Competing interests}

The authors in this study declare no conflict of interest.

\section{Author details}

${ }^{1}$ Amir Alam Hospital Complexes, Tehran University of Medical Sciences, Sa'adi Street, Tehran, Iran. ${ }^{2}$ Department of Community Nutrition, School of Nutritional Sciences and Dietetics, Tehran University of Medical Sciences, Poursina Street, Tehran, Iran. ${ }^{3}$ Iranian Centre of Neurological Research, Neuroscience Institute, Tehran University of Medical Sciences, Tehran, Iran. ${ }^{4}$ Imam Khomeini Hospital, Tehran University of Medical Sciences, Tehran, Iran. ${ }^{5}$ Department of Internal Medicine, Amiralam Hospital, Tehran University of Medical Sciences, Tehran, Iran. ${ }^{6}$ Department of Cellular and Molecular Nutrition, School of Nutritional Sciences and Dietetics, Tehran University of Medical Sciences, Poursina Street, PO Box: 14155-6446, Tehran, Iran. ${ }^{7}$ Department of Nutrition, School of Nutritional Sciences and Dietetics, Tehran University of Medical Sciences, Poursina Street, Tehran, Iran. ${ }^{8}$ Department of Anesthesiology, Amir Alam Hospital Complexes, Tehran University of Medical Sciences, Sa'adi Street, Tehran, Iran. ${ }^{9}$ Honours Cellular Anatomical Physiology, University of British Columbia, Vancouver, BC, Canada.

Received: 11 March 2021 Accepted: 14 July 2021

Published online: 23 July 2021

\section{References}

1. Namazi N, Heshmati J, Tarighat-Esfanjani A. Supplementation with riboflavin (vitamin B2) for migraine prophylaxis in adults and children: a review. Int J Vitam Nutr Res Internationale Zeitschrift fur Vitamin- und Ernahrungsforschung Journal international de vitaminologie et de nutrition. 2015;85(1-2):79-87.

2. Malhotra R. Understanding migraine: potential role of neurogenic inflammation. Ann Indian Acad Neurol. 2016;19(2):175-82.

3. Durham P, Papapetropoulos S. Biomarkers associated with migraine and their potential role in migraine management. Headache J Head Face Pain. 2013;53(8):1262-77.
4. Longoni M, Ferrarese C. Inflammation and excitotoxicity: role in migraine pathogenesis. Neurol Sci. 2006;27(2):s107-10.

5. DosSantos MF, Holanda-Afonso RC, Lima RL, DaSilva AF, Moura-Neto V. The role of the blood-brain barrier in the development and treatment of migraine and other pain disorders. Front Cell Neurosci. 2014;8:302.

6. Saegusa H, Tanabe T. N-type voltage-dependent Ca2+ channel in nonexcitable microglial cells in mice is involved in the pathophysiology of neuropathic pain. Biochem Biophys Res Commun. 2014;450(1):142-7.

7. Lambru G, Andreou AP, Guglielmetti M, Martelletti P. Emerging drugs for migraine treatment: an update. Expert Opin Emerg Drugs. 2018;23(4):301-18.

8. Brietzke E, Mansur RB, Grassi-Oliveira R, Soczynska JK, Mclntyre RS. Inflammatory cytokines as an underlying mechanism of the comorbidity between bipolar disorder and migraine. Med Hypotheses. 2012;78(5):601-5

9. Mohammadi S, Saghaeian-Jazi M, Sedighi S, Memarian A. Sodium valproate modulates immune response by alternative activation of monocyte-derived macrophages in systemic lupus erythematosus. Clin Rheumatol. 2018;37(3):719-27.

10. Khan S, Jena G, Tikoo K, Kumar V. Valproate attenuates the proteinuria, podocyte and renal injury by facilitating autophagy and inactivation of NF-kB/iNOS signaling in diabetic rat. Biochimie. 2015;110:1-16.

11. Manzano-Moreno FJ, Costela-Ruiz VJ, Melguizo-Rodríguez L, IllescasMontes R, García-Martínez O, Ruiz C, et al. Inhibition of VEGF gene expression in osteoblast cells by different NSAIDs. Arch Oral Biol. 2018;92:75-8.

12. Voloshyna I, Kasselman LJ, Carsons SE, Littlefield MJ, Gomolin IH, De Leon J, et al. COX-2-dependent and independent effects of COX-2 inhibitors and NSAIDs on proatherogenic changes in human monocytes/macrophages. J Investig Med. 2017;65(3):694-704.

13. Prangsaengtong O, Jantaree P, Lirdprapamongkol K, Ngiwsara L, Svasti J, Koizumi K. Aspirin suppresses components of lymphangiogenesis and lymphatic vessel remodeling by inhibiting the NF-KB/NCAM-1 pathway in human lymphatic endothelial cells. Vasc Med. 2018;23(3):201-11.

14. Rafiee $L$, Hajhashemi V, Javanmard SH. In vitro and in vivo modulation of LPS and carrageenan-induced expression of inflammatory genes by amitriptyline. J Pharm Pharmacogn Res. 2017;5(3):144-55.

15. Xiao L, Ding M, Fernandez A, Zhao P, Jin L, Li X. Curcumin alleviates lumbar radiculopathy by reducing neuroinflammation, oxidative stress and nociceptive factors. Eur Cell Mater. 2017;33:279.

16. Simopoulos AP. Omega-3 fatty acids in inflammation and autoimmune diseases. J Am Coll Nutr. 2002;21(6):495-505.

17. Stanić Z. Curcumin, a compound from natural sources, a true scientific challenge-a review. Plant Foods Hum Nutr. 2017;72(1):1-12.

18. Sasaki H, Sunagawa $Y$, Takahashi $K$, Imaizumi A, Fukuda H, Hashimoto T, et al. Innovative preparation of curcumin for improved oral bioavailability. Biol Pharm Bull. 2011:34(5):660-5.

19. Kanai M, Imaizumi A, Otsuka Y, Sasaki H, Hashiguchi M, Tsujiko K, et al. Dose-escalation and pharmacokinetic study of nanoparticle curcumin, a potential anticancer agent with improved bioavailability, in healthy human volunteers. Cancer Chemother Pharmacol. 2012;69(1):65-70.

20. Soleimani V, Sahebkar A, Hosseinzadeh H. Turmeric (Curcuma longa) and its major constituent (curcumin) as nontoxic and safe substances. Phytother Res. 2018;32(6):985-95.

21. Chang C-H, Tseng P-T, Chen N-Y, Lin P-C, Lin P-Y, Chang JP-C, et al. Safety and tolerability of prescription omega-3 fatty acids: A systematic review and meta-analysis of randomized controlled trials. Prostaglandins Leukot Essent Fatty Acids. 2018;129:1-12.

22. Abdolahi M, Jafarieh A, Sarraf P, Sedighiyan M, Yousefi A, Tafakhori A, et al. The neuromodulatory effects of $\omega-3$ fatty acids and nano-curcumin on the COX-2/iNOS network in migraines: A clinical trial study from gene expression to clinical symptoms. Endocr Metab Immune Disord Drug Targets Former Curr Drug Targets Immune, Endocr Metab Disord. 2019;19(6):874-84.

23. Abdolahi M, Sarraf $P$, Javanbakht MH, Honarvar NM, Hatami M, Soveyd N, et al. A novel combination of $\omega-3$ fatty acids and nano-curcumin modulates interleukin- 6 gene expression and high sensitivity C-reactive protein serum levels in patients with migraine: a randomized clinical trial study. CNS Neurol Disord Drug Targets Former Curr Drug Targets CNS Neurol Disord. 2018;17(6):430-8. 
24. Bisht K, Wagner K-H, Bulmer AC. Curcumin, resveratrol and flavonoids as anti-inflammatory, cyto-and DNA-protective dietary compounds. Toxicology. 2010;278(1):88-100.

25. Bauer I, Crewther S, Pipingas A, Sellick L, Crewther D. Does omega-3 fatty acid supplementation enhance neural efficiency? A review of the literature. Hum Psychopharmacol Clin Exp. 2014;29(1):8-18.

26. Bazan NG, Molina MF, Gordon WC. Docosahexaenoic acid signalolipidomics in nutrition: significance in aging, neuroinflammation, macular degeneration, Alzheimer's, and other neurodegenerative diseases. Annu Rev Nutr. 2011;31:321-51.

27. Ji R-R, Xu Z-Z, Strichartz G, Serhan CN. Emerging roles of resolvins in the resolution of inflammation and pain. Trends Neurosci. 2011;34(11):599-609.

28. Saw CLL, Huang Y, Kong A-N. Synergistic anti-inflammatory effects of low doses of curcumin in combination with polyunsaturated fatty acids: docosahexaenoic acid or eicosapentaenoic acid. Biochem Pharmacol. 2010;79(3):421-30.

29. Soveyd N, Abdolahi M, Djalali M, Hatami M, Tafakhori A, Sarraf P, et al. The combined effects of $\omega$-3 fatty acids and nano-curcumin supplementation on intercellular adhesion molecule-1 (ICAM-1) gene expression and serum levels in migraine patients. CNS Neurol Disord Drug Targets Former Curr Drug Targets-CNS Neurol Disord. 2017;16(10):1120-6.

30. Abdolahi M, Tafakhori A, Togha M, Okhovat AA, Siassi F, Eshraghian MR, et al. The synergistic effects of $\omega-3$ fatty acids and nano-curcumin supplementation on tumor necrosis factor (TNF)-a gene expression and serum level in migraine patients. Immunogenetics. 2017;69(6):371-8.

31. Honarvar NM, Soveid N, Abdolahi M, Djalali M, Hatami M, Karzar NH. AntiNeuroinflammatory Properties of n-3 Fatty Acids and Nano-Curcumin on Migraine Patients from Cellular to Clinical Insight: A Randomized Double-Blind and Placebo-Controlled Trial. Endocr Metab Immune Disord Drug Targets Former Curr Drug Targets Immune Endocr Metab Disord. 2021;21(2):365-73.

32. Ward TN. Migraine diagnosis and pathophysiology. CONTINUUM Lifelong Learn Neurol. 2012;18(4):753-63.

33. Vignini A, Nanetti L, Moroni C, Testa R, Sirolla C, Marra M, et al. A study on the action of vitamin E supplementation on plasminogen activator inhibitor type 1 and platelet nitric oxide production in type 2 diabetic patients. Nutr Metab Cardiovasc Dis. 2008;18(1):15-22.

34. Mottaghi A, Salehi E, Keshvarz A, Sezavar H, Saboor-Yaraghi A-A. The influence of vitamin A supplementation on Foxp3 and TGF- $\beta$ gene expression in atherosclerotic patients. Lifestyle Genomics. 2012;5(6):314-26.

35. Poreba M, Mostowik M, Siniarski A, Golebiowska-Wiatrak R, Malinowski KP, Haberka M, et al. Treatment with high-dose n-3 PUFAs has no effect on platelet function, coagulation, metabolic status or inflammation in patients with atherosclerosis and type 2 diabetes. Cardiovasc Diabetol. 2017;16(1):50.

36. Yang Y, Lu N, Chen D, Meng L, Zheng Y, Hui R. Effects of $n-3$ PUFA supplementation on plasma soluble adhesion molecules: a meta-analysis of randomized controlled trials. Am J Clin Nutr. 2012;95(4):972-80.

37. Liu W, Yuan J, Zhu H, Zhang X, Li L, Liao X, et al. Curcumin reduces brain-infiltrating $T$ lymphocytes after intracerebral hemorrhage in mice. Neurosci Lett. 2016;620:74-82.
38. Stahl A, Sapieha P, Connor KM, SanGiovanni JP, Chen J, Aderman CM, et al. PPARY mediates a direct antiangiogenic effect of $\omega 3$-PUFAs in proliferative retinopathy. Circ Res. 2010;107(4):495-500.

39. Sun C, Alkhoury K, Wang YI, Foster GA, Radecke CE, Tam K, et al. IRF-1 and miRNA126 modulate VCAM-1 expression in response to a high-fat meal. Circ Res. 2012;111(8):1054-64.

40. Shen J, Hafeez A, Stevenson J, Yang J, Yin C, Li F, et al. Omega-3 fatty acid supplement prevents development of intracranial atherosclerosis. Neuroscience. 2016;334:226-35.

41. Huang CY, Sheu WHH, Chiang AN. Docosahexaenoic acid and eicosapentaenoic acid suppress adhesion molecule expression in human aortic endothelial cells via differential mechanisms. Mol Nutr Food Res. 2015;59(4):751-62.

42. Yoshihara T, Shimada K, Fukao K, Sai E, Sato-Okabayashi Y, Matsumori R, et al. Omega 3 polyunsaturated fatty acids suppress the development of aortic aneurysms through the inhibition of macrophage-mediated inflammation. Circ J. 2015;79(7):1470-8.

43. Bittner S, Ruck T, Schuhmann MK, Herrmann AM, ou Maati HM, Bobak N, et al. Endothelial TWIK-related potassium channel-1 (TREK1) regulates immune-cell trafficking into the CNS. Nat Med. 2013:19(9):1161.

44. Binion DG, Heidemann J, Li MS, Nelson VM, Otterson MF, Rafiee P. Vascular cell adhesion molecule-1 expression in human intestinal microvascular endothelial cells is regulated by PI 3-kinase/Akt/MAPK NF-KB: inhibitory role of curcumin. Am J Physiol Gastrointest Liver Physiol. 2009;297(2):G259-68

45. Pan $Y$, Zhang $X$, Wang $Y$, Cai $L$, Ren $L$, Tang $L$, et al. Targeting JNK by a new curcumin analog to inhibit NF-kB-mediated expression of cell adhesion molecules attenuates renal macrophage infiltration and injury in diabetic mice. PLoS ONE. 2013;8(11):e79084.

46. Engelhardt B. Molecular mechanisms involved in T cell migration across the blood-brain barrier. J Neural Transm. 2006;113(4):477-85.

47. Khanna S, Park H-A, Sen CK, Golakoti T, Sengupta K, Venkateswarlu S, et al. Neuroprotective and antiinflammatory properties of a novel demethylated curcuminoid. Antioxid Redox Signal. 2009;11(3):449-68.

48. Lee C-W, Lin C-C, Luo S-F, Lee H-C, Lee I-T, Aird WC, et al. Tumor necrosis factor-a enhances neutrophil adhesiveness: induction of vascular cell adhesion molecule-1 via activation of Akt and CaM kinase II and modifications of histone acetyltransferase and histone deacetylase 4 in human tracheal smooth muscle cells. Mol Pharmacol. 2008;73(5):1454-64.

49. Xia L, Xie H, Yu Y, Zhou H, Wang T, Yan J. The Effects of NF-kB and c-Jun/ AP-1 on the expression of prothrombotic and proinflammatory molecules induced by anti- $\beta 2$ GPI in mouse. PLoS ONE. 2016;11(2):e0147958.

\section{Publisher's Note}

Springer Nature remains neutral with regard to jurisdictional claims in published maps and institutional affiliations.

Ready to submit your research? Choose BMC and benefit from

- fast, convenient online submission

- thorough peer review by experienced researchers in your field

- rapid publication on acceptance

- support for research data, including large and complex data types

- gold Open Access which fosters wider collaboration and increased citations

- maximum visibility for your research: over 100M website views per year

At BMC, research is always in progress.

Learn more biomedcentral.com/submissions 